\title{
Diaphragm Thickness Measurement in Computed Tomography: Intra- and Inter-Observer Agreement
}

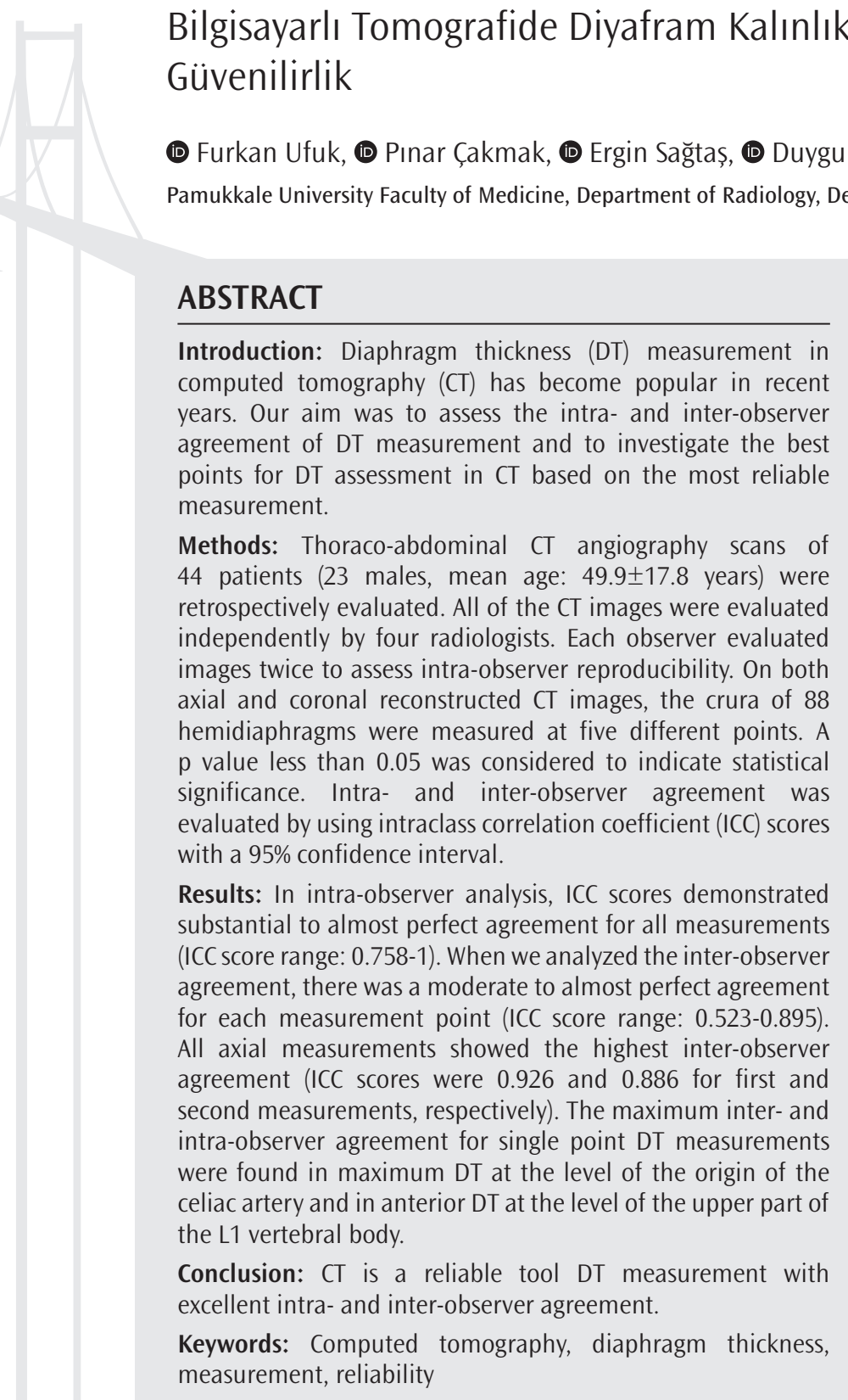

\section{öz}

Amaç: Çeșitli hastalıklarda bilgisayarlı tomografide (BT) diyafram kalınlığı (DK) ölçümü son yıllarda popüler hale gelmiștir. Amacımız, DK ölçümünün gözlemci içi ve gözlemciler arası anlașmasını değerlendirmek ve en güvenilir ölçümlere dayanarak BT'de en iyi DK ölçümü yerini araştırmaktır.

Yöntemler: DK ölçümünde 44 hastanın (23 erkek, ortalama yaș; 49,9 $\pm 17,8$ ) torako-abdominal BT anjiyografisi retrospektif olarak değerlendirildi. Tüm BT görüntüleri dört radyolog tarafından bağımsız olarak değerlendirildi. Her gözlemci, gözlemciler arası tekrarlanabilirliği değerlendirmek için görüntüleri iki kez değerlendirdi. Hem aksiyal hem de koronal rekonstrüksiyon yapılmış BT görüntülerinde, 88 hemidiyaframın krusları beş farklı noktada ölçülmüștür. İstatistiksel anlamlılığı göstermek için 0,05’ten küçük bir $p$ değeri göz önüne alınmıştır. Gözlemci içi ve gözlemciler arası anlașma, \%95 güven aralığında sınıf içi korelasyon katsayısı (ICC) skorları kullanılarak değerlendirildi.

Bulgular: Gözlemci içi arası analizde, ICC skorları, tüm ölçümler için iyi - neredeyse mükemmel bir anlaşma göstermiștir (ICC skorları aralığı; 0,758-1). Gözlemciler arası anlașmayı incelediğimizde, her bir ölçüm noktası için orta - neredeyse mükemmel bir anlaşma vardı (ICC skoru aralı̆̆ı, 0,5230,895). Tüm aksiyal ölçüm değerleri en yüksek gözlemciler arası anlașmayı gösterdi (ICC skorları sırasıyla birinci ve ikinci ölçümler için 0,926 ve 0,886 idi). Tek nokta DK ölçümleri için en iyi gözlemci içi ve gözlemciler arası anlaşma, çölyak arter çıımı düzeyinde maksimum DK ve L1 vertebra gövdesinin üst kısmı seviyesinde anterior DK ölçülmesinde bulundu.

Sonuç: Bilgisayarlı tomografi, yüksek gözlemci içi ve gözlemciler arası uyum nedeniyle DK ölçümü için güvenilir bir araçtır.

Anahtar Kelimeler: Bilgisayarlı tomografi, diyafram kalınlığı, ölçüm, güvenilirlik

(c) Copyright 2019 by the Istanbul Training and Research Hospital/Istanbul Medical Journal published by Galenos Publishing House. 


\section{Introduction}

The diaphragm is the major inspiratory muscle with a dome-like shape and measurement of diaphragm thickness (DT) in various disorders has become popular in recent years. Decreased DT on ultrasound was shown to correlate with reduced myocyte cross-sectional area in a porcine model (1). Measurement of DT in computed tomography (CT) has been shown to be successful in the assessment of the success of diaphragm pacing system in amyotrophic lateral sclerosis (ALS) patients (2), detection of diaphragmatic thinning due to mechanical ventilator therapy and sepsis $(3,4)$, and the diagnosis of unilateral diaphragm paralysis (5). In previous studies (2-5), DT measurement in CT was performed by single observers. The main limitation of CT in DT measurement is the absence of a consensus on reliable measurement locations (points). This may lead to variability in the performance of CT in DT measurements, which may weaken the reliability of $\mathrm{CT}$ measurements. To the best of our knowledge, no study has investigated the best points for DT measurement and agreement between observers.

Our aim was to assess the intra- and inter-observer agreement of DT measurement and to investigate the best points for DT assessment in CT based on the most reliable measurement.

\section{Methods}

This retrospective study started after our institutional Pamukkale University Local Ethics Committee approved letter of application (decision no: 60116787-20/85543). Informed consent was not obtained from the patients because of retrospective nature of the study.

\section{Patients}

Patients who underwent thoraco-abdominal CT angiography for suspected acute aortic syndrome between January 2016 and July 2017 were included the study. The exclusion criteria were as follows: pulmonary pathology that can affect DT measurement (such as lower lob atelectasis, mass or pleural effusion), focal or diffuse diaphragmatic crus defect and $\mathrm{CT}$ examinations with inadequate diagnostic quality due to motion artifacts. A total of 44 patients (23 males, mean age: $49.9+17.8$ years, range: $18-85$ years) were included in the study.

\section{Computed Tomography Scanning Protocol}

All thoraco-abdominal CT angiography scans were obtained in the supine position with maximum inspiration using a multi-detector CT scanner (Brilliance 16; Philips Healthcare, Best, Netherlands). The area between the thoracic inlet and the deep costophrenic sulcus was scanned. The scanning parameters were as follows: tube voltage, 120 kV; tube current, $100 \mathrm{mAs}$; collimation, $16 \times 0.75 \mathrm{~mm}$; field of view, 300 $\mathrm{mm}$; matrix, 512x512; rotation time, $0.75 \mathrm{~s}$; table speed, $15 \mathrm{~mm} / \mathrm{s}$ and beam pitch, 0.94. All CT images were reconstructed in transverse and coronal planes at $1.5 \mathrm{~mm}$ slice thickness.

\section{Radiological Evaluation}

All CT images were evaluated independently by four radiologists with various experience (3, 9, 12 and 20 years) on the same workstation (Extended Brilliance Workspace, Philips Healthcare). Observers were blinded to measurements of each other. Each observer evaluated the images twice to assess intra-observer reproducibility. The second assessment was done at least three months after the first to prevent recall.

Five measurements were performed on both axial and coronal images for each hemidiaphragm (88 hemidiaphragms) thickness. CT images were evaluated in the mediastinal window (window center, $90 \mathrm{HU}$; window width, $350 \mathrm{HU}$ ) and magnification was freely modifiable. Measurements were performed as described by Sukkasem et al. (5). On both axial and coronal reconstructed $\mathrm{CT}$ images, the crura of the hemidiaphragms were measured at the level of the origin of the celiac artery, and minimum and maximum DT were recorded. In addition, measurements were recorded for each crura at the level of the upper part of the L1 vertebral body along the anterior, middle and posterior aspects of the vertebral body on axial images and upper, middle and lower aspects of the vertebral body on coronal images (Figure 1).

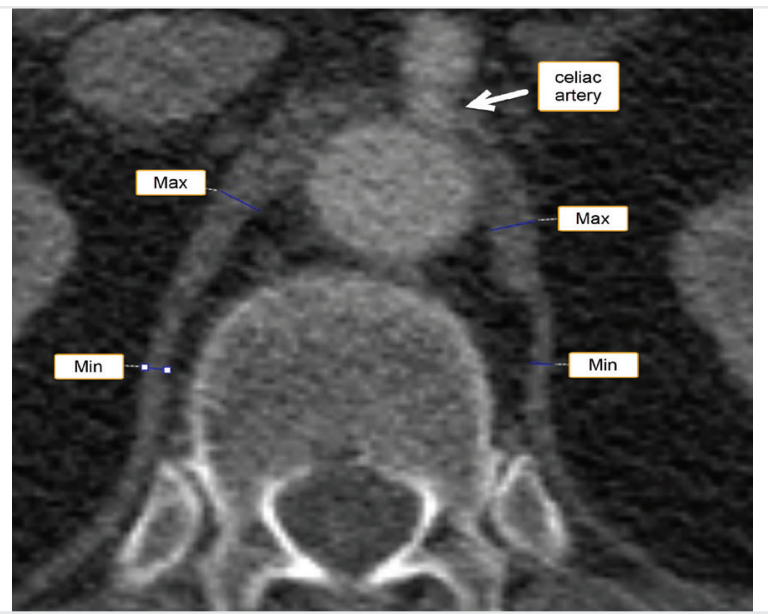

Figure 1. Points of diaphragm thickness measurements. a) Axial computed tomography scan at the celiac artery origin level (arrow) shows maximum and minimum diaphragm thickness measurements

Max: maximum diaphragm thickness at the level of the origin of the celiac artery, Min: minimum diaphragm thickness at the level of the origin of the celiac artery

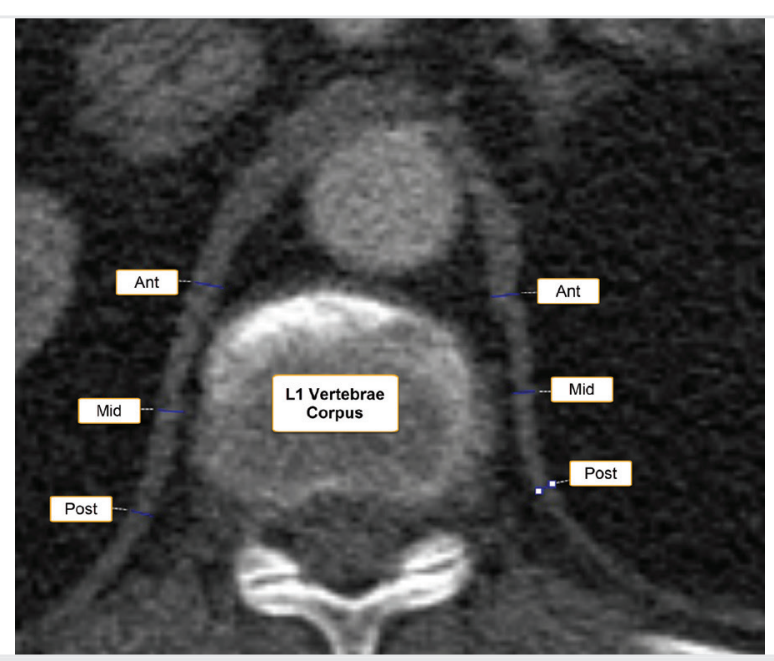

Figure 1. b) Axial computed tomography scan at the L1 vertebra corpus level shows anterior, mid and posterior diaphragm thickness measurements

Ant:anterior diaphragm thickness at the level of the upper part of the L1 vertebral body on axial images, Mid:mid diaphragm thickness at the level of the upper part of the L1 vertebral body, Post: posterior diaphragm thickness at the level of the upper part of the L1 vertebral body on axial images 
Ufuk et al. The Diaphragm Thickness Measurements on CT

Table 1. The diaphragm thickness measurement results of patients and intra-observer agreement scores for each measurement

\begin{tabular}{|c|c|c|c|c|c|}
\hline & $\begin{array}{l}\text { First evaluation Mean } \pm \text { SD } \\
(\mathrm{mm})\end{array}$ & $\begin{array}{l}\text { Second evaluation Mean } \pm \\
\text { SD }(\mathrm{mm})\end{array}$ & $\begin{array}{l}\text { Intraclass correlation } \\
\text { coefficient }\end{array}$ & $\begin{array}{l}\text { Lower bound } \\
(95 \% \mathrm{Cl})\end{array}$ & $\begin{array}{l}\text { Upper bound } \\
(95 \% \mathrm{Cl})\end{array}$ \\
\hline & \multicolumn{3}{|l|}{ Axial (observer 1) } & & \\
\hline $\operatorname{Max}$ & $7.3 \pm 1.9$ & $7.7 \pm 1.8$ & 0.951 & 0.911 & 0.995 \\
\hline Min & $2.9 \pm 0.6$ & $3 \pm 0.4$ & 0.915 & 0.845 & 0.951 \\
\hline Ant & $5.3 \pm 1.5$ & $5.1 \pm 1.3$ & 0.94 & 0.891 & 0.992 \\
\hline Mid & $3.6 \pm 0.8$ & $3.5 \pm 0.6$ & 0.937 & 0.885 & 0.966 \\
\hline \multirow[t]{2}{*}{ Post } & $3.1 \pm 0.8$ & $3.2 \pm 0.5$ & 0.895 & 0.808 & 0.943 \\
\hline & \multicolumn{3}{|l|}{ Coronal (observer 1) } & & \\
\hline $\operatorname{Max}$ & $6.2 \pm 1.8$ & $6.9 \pm 1.9$ & 0.912 & 0.866 & 0.986 \\
\hline Min & $2.2 \pm 0.6$ & $2.4 \pm 0.5$ & 0.905 & 0.868 & 0.961 \\
\hline Low & $2.5 \pm 0.6$ & $2.9 \pm 1.1$ & 0.88 & 0.872 & 0.905 \\
\hline Mid & $2.9 \pm 1$ & $3 \pm 0.7$ & 0.924 & 0.860 & 0.958 \\
\hline \multirow[t]{2}{*}{ Upp } & $4.6 \pm 1.7$ & $4.1 \pm 1.4$ & 0.774 & 0.659 & 0.899 \\
\hline & \multicolumn{3}{|l|}{ Axial (observer 2) } & & \\
\hline $\operatorname{Max}$ & $6.5 \pm 2.1$ & $6.8 \pm 1.8$ & 0.962 & 0.926 & 0.991 \\
\hline Min & $2.8 \pm 0.6$ & $3 \pm 0.4$ & 0.948 & 0.904 & 0.972 \\
\hline Ant & $5.1 \pm 1.3$ & $5.1 \pm 1.3$ & 1 & 1 & 1 \\
\hline Mid & $3.7 \pm 1$ & $3.5 \pm 0.8$ & 0.966 & 0.937 & 0.981 \\
\hline \multirow[t]{2}{*}{ Post } & $3.3 \pm 0.7$ & $3 \pm 0.5$ & 0.95 & 0.909 & 0.973 \\
\hline & \multicolumn{3}{|l|}{ Coronal (observer 2) } & & \\
\hline Max & $7.2 \pm 2.4$ & $6.6 \pm 1.4$ & 0.795 & 0.773 & 0.832 \\
\hline Min & $2.2 \pm 0.5$ & $2.3 \pm 0.4$ & 0.885 & 0.813 & 0.951 \\
\hline Low & $3 \pm 1.5$ & $3.3 \pm 1.2$ & 0.825 & 0.763 & 0.879 \\
\hline Mid & $3.4 \pm 0.8$ & $2.9 \pm 0.4$ & 0.785 & 0.718 & 0.834 \\
\hline \multirow[t]{2}{*}{ Upp } & $4.9 \pm 0.5$ & $4.5 \pm 0.4$ & 0.812 & 0.782 & 0.935 \\
\hline & \multicolumn{3}{|l|}{ Axial (observer 3) } & & \\
\hline Max & $7.3 \pm 2.4$ & $7.1 \pm 2$ & 0.972 & 0.947 & 0.990 \\
\hline Min & $2.9 \pm 0.7$ & $2.9 \pm 0.5$ & 0.904 & 0.882 & 0.972 \\
\hline Ant & $5.2 \pm 1.6$ & $5.2 \pm 1.3$ & 0.975 & 0.955 & 0.986 \\
\hline Mid & $4 \pm 1.3$ & $4.1 \pm 1.2$ & 0.923 & 0.869 & 0.952 \\
\hline \multirow[t]{2}{*}{ Post } & $3.6 \pm 0.9$ & $3.7 \pm 0.6$ & 0.913 & 0.840 & 0.952 \\
\hline & \multicolumn{3}{|l|}{ Coronal (observer 3) } & & \\
\hline Max & $7.2 \pm 2.4$ & $7.1 \pm 1.8$ & 0.947 & 0.903 & 0.971 \\
\hline Min & $2.3 \pm 0.5$ & $2.7 \pm 0.4$ & 0.822 & 0.767 & 0.856 \\
\hline Low & $3.2 \pm 1.4$ & $4.1 \pm 1.2$ & 0.758 & 0.659 & 0.888 \\
\hline Mid & $3.5 \pm 1.1$ & $3.5 \pm 0.9$ & 0.949 & 0.913 & 0.963 \\
\hline \multirow[t]{2}{*}{ Upp } & $4.7 \pm 0.8$ & $4.2 \pm 0.7$ & 0.767 & 0.712 & 0.835 \\
\hline & \multicolumn{3}{|l|}{ Axial (observer 4) } & & \\
\hline Max & $6.8 \pm 1.9$ & $6.7 \pm 1.6$ & 0.974 & 0.953 & 0.986 \\
\hline Min & $2.6 \pm 0.5$ & $2.6 \pm 0.3$ & 0.951 & 0.910 & 0.973 \\
\hline Ant & $4.9 \pm 1.5$ & $4.5 \pm 1.1$ & 0.952 & 0.912 & 0.974 \\
\hline Mid & $3.8 \pm 1.1$ & $3.7 \pm 0.7$ & 0.939 & 0.888 & 0.967 \\
\hline \multirow[t]{2}{*}{ Post } & $3.3 \pm 1.1$ & $3.2 \pm 0.8$ & 0.95 & 0.928 & 0.978 \\
\hline & \multicolumn{3}{|l|}{ Coronal plane (observer 4) } & & \\
\hline Max & $6.3 \pm 2.3$ & $6.9 \pm 1.7$ & 0.867 & 0.820 & 0.882 \\
\hline Min & $2.2 \pm 0.6$ & $2.5 \pm 0.4$ & 0.882 & 0.817 & 0.936 \\
\hline Low & $3.6 \pm 1.8$ & $4.1 \pm 1.6$ & 0.788 & 0.712 & 0.893 \\
\hline
\end{tabular}


Table 1. Continued

\begin{tabular}{|c|c|c|c|c|c|}
\hline & $\begin{array}{l}\text { First evaluation Mean } \pm \text { SD } \\
(\mathrm{mm})\end{array}$ & $\begin{array}{l}\text { Second evaluation Mean } \pm \\
\text { SD }(\mathrm{mm})\end{array}$ & $\begin{array}{l}\text { Intraclass correlation } \\
\text { coefficient }\end{array}$ & $\begin{array}{l}\text { Lower bound } \\
(95 \% \mathrm{CI})\end{array}$ & $\begin{array}{l}\text { Upper bound } \\
(95 \% \mathrm{CI})\end{array}$ \\
\hline & \multicolumn{3}{|l|}{ Coronal plane (observer 4) } & & \\
\hline Mid & $3.3 \pm 0.9$ & $3.7 \pm 0.7$ & 0.83 & 0.782 & 0.874 \\
\hline Upp & $4.1 \pm 0.8$ & $4.8 \pm 0.6$ & 0.768 & 0.638 & 0.826 \\
\hline
\end{tabular}

\section{Table 2. The inter-observer agreement for the first and second} measurements

$\begin{array}{lll}\begin{array}{l}\text { Intraclass correlation } \\ \text { coefficient }\end{array} & \begin{array}{l}\text { Lower bound } \\ (\mathbf{9 5 \%} \mathrm{Cl})\end{array} & \begin{array}{l}\text { Upper bound } \\ (\mathbf{9 5 \%} \mathrm{Cl})\end{array}\end{array}$

First measurements

\begin{tabular}{|c|c|c|c|}
\hline \multicolumn{4}{|c|}{ Axial } \\
\hline Max & 0.895 & 0.773 & 0.947 \\
\hline Min & 0.564 & 0.349 & 0.660 \\
\hline Ant & 0.823 & 0.727 & 0.900 \\
\hline Mid & 0.753 & 0.649 & 0.873 \\
\hline Post & 0.722 & 0.533 & 0.887 \\
\hline All & 0.926 & 0.873 & 0.958 \\
\hline \multicolumn{4}{|c|}{ Coronal } \\
\hline Max & 0.753 & 0.610 & 0.853 \\
\hline Min & 0.625 & 0.439 & 0.789 \\
\hline Low & 0.742 & 0.607 & 0.854 \\
\hline Mid & 0.614 & 0.453 & 0.792 \\
\hline Upp & 0.705 & 0.523 & 0.822 \\
\hline All & 0.790 & 0.684 & 0.870 \\
\hline \multicolumn{4}{|c|}{ Second measurements } \\
\hline \multicolumn{4}{|c|}{ Axial } \\
\hline Max & 0.817 & 0.765 & 0.909 \\
\hline Min & 0.782 & 0.723 & 0.904 \\
\hline Ant & 0.860 & 0.773 & 0.918 \\
\hline Mid & 0.721 & 0.558 & 0.851 \\
\hline Post & 0.736 & 0.591 & 0.860 \\
\hline All & 0.886 & 0.832 & 0.926 \\
\hline \multicolumn{4}{|c|}{ Coronal } \\
\hline Max & 0.613 & 0.383 & 0.772 \\
\hline Min & 0.523 & 0.252 & 0.707 \\
\hline Low & 0.640 & 0.479 & 0.804 \\
\hline Mid & 0.762 & 0.669 & 0.876 \\
\hline Upp & 0.585 & 0.294 & 0.734 \\
\hline All & 0.776 & 0.662 & 0.838 \\
\hline
\end{tabular}

Max: maximum diaphragm thickness at the level of the origin of the celiac artery, Min: minimum diaphragm thickness at the level of the origin of the celiac artery, Ant: anterior diaphragm thickness at the level of the upper part of the L1 vertebral body on axial images, Mid: mid diaphragm thickness at the level of the upper part of the $L 1$ vertebral body, Post: posterior diaphragm thickness at the level of the upper part of the L1 vertebral body on axial images, Upp: diaphragm thickness at the upper aspects of the L1 vertebral body on coronal images, Low: diaphragm thickness at the lower aspects of the L1 vertebral body on coronal images, $\mathrm{Cl}$ : confidence interval

\section{Statistical Analysis}

Statistical analysis was performed using Statistical Package for the Social Sciences (SPSS) for Windows (Version 24.0, SPSS Inc. IBM Corp, Chicago, IL). The distribution of normality for each continuous variable group was calculated by Kolmogorov-Smirnov Z-test. Student's t-test was used for comparisons of paired samples. A p value less than 0.05 was considered to indicate statistical significance. Intra- and inter-observer agreement was evaluated by using intraclass correlation coefficient (ICC) scores with a 95\% confidence interval $(\mathrm{Cl})$. Intra- and inter-observer agreement was categorized as follows: $0.01-0.20$ as poor, $0.21-0.40$ as fair, $0.41-0.60$ as moderate, $0.61-0.80$ as substantial and $0.81-1.00$ as almost perfect.

\section{Results}

In all groups, DT values showed normal distribution. The results of DT measurements of 44 patients and intra-observer agreement scores for each measurement are shown in Table 1. The inter-observer agreement

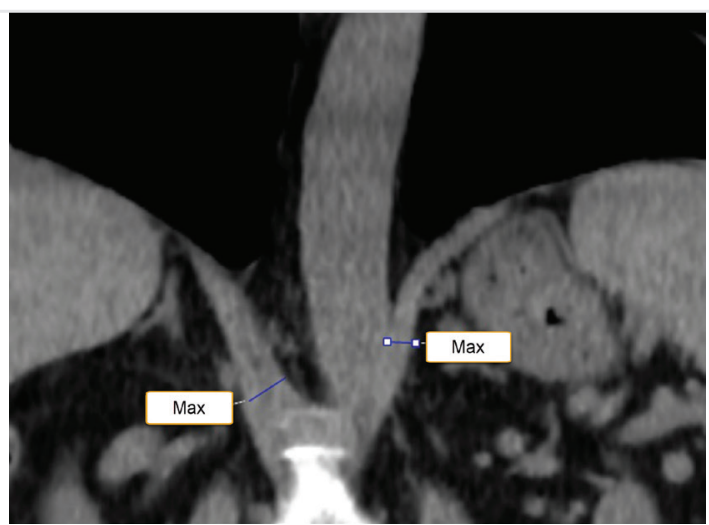

Figure 1. c) Coronal reformatted computed tomography images at the celiac artery level shows maximum and minimum diaphragm thickness measurements

Max: maximum diaphragm thickness at the level of the origin of the celiac artery

Table 3. Comparison of first and second measurements by different observers for all measurements

\begin{tabular}{|l|l|l|l|l|}
\hline Second measurement & \multicolumn{3}{|l}{ First measurement $\mathbf{p}$ value } \\
\hline $\mathbf{p}$ value & OBS-1 & OBS-2 & OBS-3 & OBS-4 \\
\hline OBS-1 & 0.465 & 0.212 & 0.589 & 0.674 \\
\hline OBS-2 & 0.355 & 0.273 & 0.740 & 0.688 \\
\hline OBS-3 & 0.289 & 0.068 & 0.688 & 0.723 \\
\hline OBS-4 & 0.448 & $0.045^{*}$ & 0.759 & 0.812 \\
\hline $\begin{array}{l}\text { OBS: indicates observer } \\
\text { *Statistically significant value }\end{array}$ & & & & \\
\hline
\end{tabular}


for the first and second measurements is given in Table 2. There was a statistically significant difference between the measurements of observer 2 and observer 4 when all DT measurements were compared in the axial and coronal plane $(p=0.045)$ (Table 3).

In intra-observer analysis, ICC scores demonstrated substantial to almost perfect agreement for all measurements (ICC scores range $=0.758-1$ ) (Table 1). When we analyzed the inter-observer agreement, there was a moderate to almost perfect agreement for each measurement points (ICC score range=0.523-0.895). All axial measurement values showed the highest inter-observer agreement (ICC scores were 0.926 and 0.886 for first and second measurements, respectively). There was a substantial agreement between observers for all coronal measurement values with ICC scores of $0.790(95 \% \mathrm{Cl}, 0.684-0.870)$ and $0.776(95 \% \mathrm{Cl}, 0.662$ 0.838 ) for the first and second measurements, respectively (Table 2).

The maximum inter- and intra-observer agreement for single point DT measurements were found in maximum DT at the level of the origin of the celiac artery and in anterior DT at the level of the upper part of the L1 vertebral body. In the coronal plane, the intra- and inter-observer agreement for DT measurements varied widely for each measurement point (Tables 1 and 2).

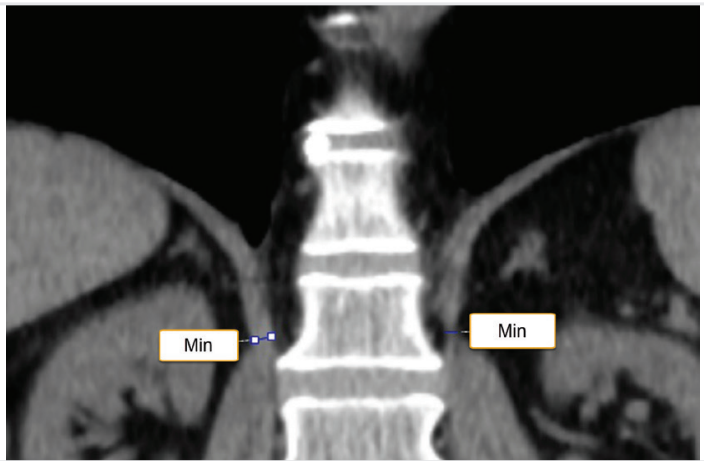

Figure 1. d) Coronal reformatted computed tomography images at the celiac artery level shows maximum and minimum diaphragm thickness measurements

Min: minimum diaphragm thickness at the level of the origin of the celiac artery

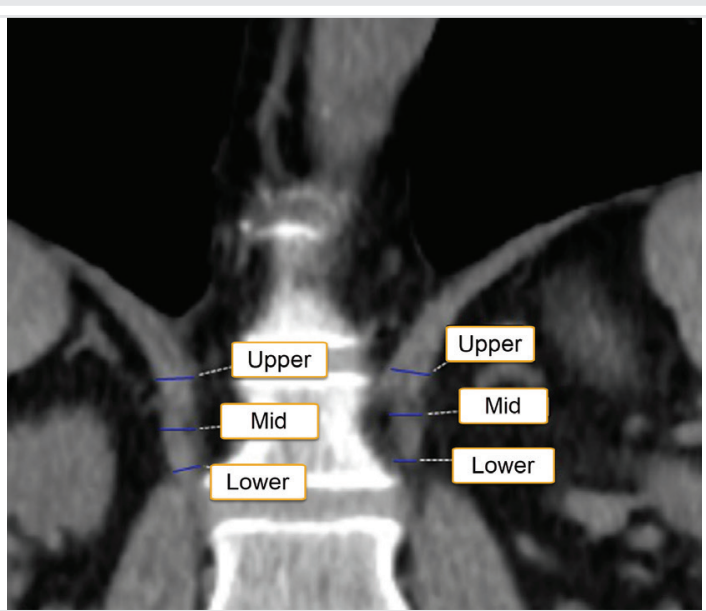

Figure 1. e) Coronal reformatted computed tomography image at the L1 vertebra corpus level shows upper, mid and lower diaphragm thickness measurements

Mid:mid diaphragm thickness at the level of the upper part of the L1 vertebral body, Upp: diaphragm thickness at the upper aspects of the L1 vertebral body on coronal images, Low: diaphragm thickness at the lower aspects of the L1 vertebral body on coronal images

\section{Discussion}

This study showed that the assessment of DT by CT has high intra and inter-observer reliability. All DT measurements showed the highest inter-observer agreement at five points (maximum, minimum thickness at the level of celiac artery origin, anterior, middle and posterior thickness at the level of L1 vertebral body) on axial CT images. There was substantial agreement between observers for all measurements on coronal CT images. The maximum inter- and intra-observer agreement for single point DT measurements were found in maximum DT at the level of the origin of the celiac artery and in anterior DT at the level of the upper part of the L1 vertebral body. In the coronal plane, the intra- and intra-observer agreement for DT measurements varied widely for each measurement point. Therefore, we suggest that if DT will be evaluated in the coronal plane, it would be appropriate to evaluate by measuring from all described 5 points.

Despite the increased use of CT for diaphragm evaluation, there is a lack of reference locations for DT measurement in CT. To the best of our knowledge, this is the first study that assessed the intra- and interobserver agreement for DT measurement in CT and that investigated the best points for measurement in CT. The inter-observer variability in our study varied from moderate to almost perfect according to the measurement points and image plane. Therefore, we can say that the image plane (axial or coronal) and location is very important for DT measurement in CT. In our study, DT measurements were performed from the upper part L1 vertebra corpus level due to blurring of the diaphragm crus by psoas muscle in the middle and lower parts of the L1 vertebra corpus level. Unlike Sukkasem et al. (5), we did not measure DT at the level of Smooth Muscle Actin (SMA) origin, due to blurring of the diaphragm crus by psoas muscle at SMA origin level in many patients.

In mechanically ventilated patients and patients with paralyzed hemidiaphragm, diaphragmatic dysfunction is an important cause of complications, such as pulmonary atelectasis, infection and hypoxemia. These complications have been shown to correlate with mortality, poor prognosis and significantly higher health costs (6-9). In addition, weakness of the diaphragm is a major cause of difficult weaning from mechanical ventilation (10). Therefore, evaluation of DT and functions is very important. It has been shown that ultrasound (US) measurements of DT have a high degree of reproducibility and decreased DT on ultrasound has been shown to correlate with reduced myocyte volume (1,9-14). Experience is important when performing DT measurement by US. For an inexperienced observer, it may be difficult to accurately measure the DT by UA in incompatible patients (14). Compared to US, CT better depicts the anatomy of the diaphragm and also demonstrates associated lung and mediastinal pathologies (15-18). However, CT is not a suitable method for only assessing DT due to radiation exposure. Therefore, it is more appropriate to assess DT on CT images which were obtained to evaluate lung or mediastinal pathology.

There are only a few studies on DT evaluation in CT (2-5). Sanli et al. (2) found that DT is an important feature in patients with ALS in whom diaphragm pacing system implantation is planned. In their study, a single observer measured DT at the level of thoracic 11-12 vertebra corpus on coronal images. The location specified for DT measurement 
is not a specific point and represents a very large area for DT measurement. In addition, they did not specify the CT slice thickness used in the study (2). Lee et al. (3) demonstrated that DT decreased in patients who underwent mechanical-ventilation therapy in CT. In that study, a radiologist measured the DT at the level of the celiac artery by using software on axial and coronal images. However, the number of patients included in the study was thirteen, which is quite small. Also, they did not specify the thickness of the CT slice used in the study (3). Jung et al. (4) found that diaphragm volume was decreased in patients with sepsis in CT. In their study, the diaphragm volumes were calculated semi-automatically by a single radiologist. However, in this study, it was not specified in which phase (inspiration-expiration) the CT images were obtained (4). Sukkasem et al. (5) found a high sensitivity and specificity in the differentiation of paralyzed and non-paralyzed hemidiaphragms when they assumed $2.5 \mathrm{~mm}$ as the threshold value of a minimum DT on axial images at the level of celiac artery in CT. In their study, all measurements were performed by one observer and the slice thickness of the CT was variable (range: 0.625 to $5 \mathrm{~mm}$ ) (5). We used a standard $1.5 \mathrm{~mm}$ slice thickness in our study. Our results demonstrated a better inter-observer agreement for axial CT images than coronal CT images. This may be due to relatively thick CT slices or due to the natural shape of the diaphragm (the shape of the dome).

Our study also has some limitations. The relatively small sample size is the first one. However, this study was not intended to determine DT values in the population. The aim of this study was to determine the best DT measurement points in CT and the reliability of DT measurement in CT. The retrospective design of the study is the second one. However, these are acceptable limitations due to the lack of similar CT studies.

\section{Conclusion}

CT is a reliable tool for DT measurement with excellent intra and interobserver reliability. This is the first study that reveals the best and reproducible measurement points and plane for DT measurements in CT. All DT measurement values at five identified points on axial CT images showed the highest inter-observer reliability. The most reliable single measurement point in the axial plane was maximum DT at the level of the celiac artery or anterior DT at the level of the upper part of the L1 vertebral body.

Ethics Committee Approval: This retrospective study started after our institutional Pamukkale University Local Ethics Committee approved letter of application (decision no: 60116787-20/85543).

Informed Consent: Informed consent was not obtained from the patients because of retrospective nature of the study.

Peer-review: Externally peer-reviewed.

Author Contributions: Concept - F.U., P.Ç.; Design - F.U., P.Ç., D.H., E.S.; Supervision - F.U., A.B.Y.; Data Collection and/or Processing - F.U., P.C.., D.H.; Analysis and/or Interpretation - F.U., D.H., A.B.Y.; Literature Search - F.U., M.A., E.S.; Writing Manuscript - F.U., D.H., M.A.; Critical Review D.H., A.B.Y.

Conflict of Interest: Authors have no conflicts of interest to declare.
Financial Disclosure: The authors declared that this study has received no financial support.

\section{References}

1. Reynolds SC, Meyyappan R, Thakkar V, Tran BD, Nolette MA, Sadarangani G, et al. Mitigation of ventilator-induced diaphragm atrophy by transvenous phrenic nerve stimulation. Am J Respir Crit Care Med 2017; 195: 339-48.

2. Sanli A, Sengun IS, Tertemiz KC, Alpaydin AO, Karacam V, Sanli BA, et al. Importance of diaphragm thickness in amyotrophic lateral sclerosis patients with diaphragm pacing system implantation. Surg Endosc 2016; 30: 154-8.

3. Lee GD, Kim HC, Yoo JW, Lee SJ, Cho YJ, Bae K, et al. Computed tomography confirms a reduction in diaphragm thickness in mechanically ventilated patients. J Crit Care 2016; 33: 47-50.

4. Jung B, Nougaret S, Conseil M, Coisel Y, Futier E, Chanques G, et al. Sepsis is associated with a preferential diaphragmatic atrophy: a critically ill patient study using tridimensional computed tomography. Anesthesiology 2014; 120 1182-91.

5. Sukkasem W, Moftah SG, Kicska G, Godwin JD, Pipavath S, Stern E. Crus atrophy: Accuracy of computed tomography in diagnosis of diaphragmatic paralysis. J Thorac Imaging 2017; 32: 383-90.

6. Vassilakopoulos T, Petrof BJ. A Stimulating Approach to Ventilator induced Diaphragmatic Dysfunction. Am J Respir Crit Care Med 2017; 195: 281-2.

7. Kim WY, Suh HJ, Hong SB, Koh Y, Lim CM. Diaphragm dysfunction assessed by ultrasonography: influence on weaning from mechanical ventilation. Crit Care Med 2011; 39: 2627-30

8. Damuth E, Mitchell JA, Bartock JL, Roberts BW, Trzeciak S. Long-term survival of critically ill patients treated with prolonged mechanical ventilation: a systematic review and meta-analysis. Lancet Respir Med 2015; 3: 544-53.

9. Dhungana A, Khilnani G, Hadda V, Guleria R. Reproducibility of diaphragm thickness measurements by ultrasonography in patients on mechanical ventilation. World J Crit Care Med 2017; 6: 185-9.

10. Dres M, Dubé B-P, Mayaux J, Delemazure J, Reuter D, Brochard L, et al. Coexistence and Impact of Limb Muscle and Diaphragm Weakness at Time of Liberation from Mechanical Ventilation in Medical Intensive Care Unit Patients. Am J Respir Crit Care Med 2017; 195: 57-66.

11. Vivier E, Mekontso Dessap A, Dimassi S, Vargas F, Lyazidi A, Thille AW, et al. Diaphragm ultrasonography to estimate the work of breathing during noninvasive ventilation. Intensive Care Med 2012; 38: 796-803.

12. Boussuges A, Gole Y, Blanc P. Diaphragmatic motion studied by m-mode ultrasonography: methods, reproducibility, and normal values. Chest 2009; 135: 391-400.

13. Goligher EC, Laghi F, Detsky ME, Farias P, Murray A, Brace D, et al. Measuring diaphragm thickness with ultrasound in mechanically ventilated patients: feasibility, reproducibility and validity. Intensive Care Med 2015; 41: 642-9.

14. Sarwal A, Walker FO, Cartwright MS. Neuromuscular ultrasound for evaluation of the diaphragm. Muscle Nerve 2013; 47: 319-29.

15. Caskey $\mathrm{Cl}$, Zerhouni EA, Fishman EK, Rahmouni AD. Aging of the diaphragm: a CT study. Radiology 1989; 171: 385-9.

16. Dovgan DJ, Lenchik L, Kaye AD. Computed tomographic evaluation of maximal diaphragmatic crural thickness. Conn Med 1994; 58: 203-6.

17. Harlaar L, Ciet P, van der Ploeg AT, Brusse E, van der Beek NAME, Wielopolski PA, et al. Imaging of respiratory muscles in neuromuscular disease: A review. Neuromuscul Disord 2018; 28: 246-56.

18. Goo HW. Four-Dimensional CT of the diaphragm in children: initial experience Korean J Radiol 2018; 19: 111-8. 